\title{
LABOR FLEXIBILIZATION AND DEREGULATION FOR NURSING WORKERS IN BRAZIL: THE PROFAE CASE
}

Solange Baraldi ${ }^{1}$

Marcia Regina Car $^{2}$

Baraldi S, Car MR. Labor flexibilization and deregulation for nursing workers in Brazil: the PROFAE case. Rev Latino-am Enfermagem 2008 março-abril; 16(2):205-11.

This study analyzed the flexibilization process of labor relations in the PROFAE Professionalization Project of Nursing Workers (Projeto de Profissionalização dos Trabalhadores da Área de Enfermagem - PROFAE) in Brazil. This qualitative study used dialectical and historical materialism as the theoretical-methodological framework. Data were collected through directed interviews with open-ended questions, and answers were submitted to discourse analysis. The obtained results evidence the flexibilization and deregulation process of labor relations in the health area in Brazil, characterized by the following elements: payment by production; fragmented labor division; criteria for variable wage payment; qualified and versatile professionals; perceived professional freedom; reduced governability and power to make decisions; multiple jobs; activity planning as a substitute for planning models, and the massive systematic operationalization of actions.

DESCRIPTORS: labor relations; nursing, supervisory; public health; international organizations

\section{LA FLEXIBILIZACIÓN Y LA DESREGULACIÓN LABORAL DE LOS TRABAJADORES DEL ÁREA DE ENFERMERÍA EN BRASIL: EL CASO PROFAE}

Este estudio analizó el proceso de flexibilización de las relaciones del trabajo en la implementación del Proyecto de Profesionalización de los Trabajadores del Área de Enfermería (PROFAE) en Brasil. Se trata de un estudio cualitativo, que tiene como marco teórico y metodológico el materialismo histórico y dialéctico. Fueron realizadas entrevistas dirigidas con cuestiones abiertas y sometidas al procedimiento de análisis del discurso. Los resultados evidenciaron el proceso de flexibilización y de desregulación de las relaciones del trabajo en el área de la salud del Brasil, caracterizado por los siguientes elementos: compensación por producción; división fragmentada del trabajo; criterios de remuneración salarial variable; profesionales calificados y polivalentes; sensación de libertad profesional; reducida gobernabilidad y de poder de decisión; múltiples vínculos; programación de actividades substituyendo modelos de planificación y maciza operacionalización sistemática de las acciones.

DESCRIPTORES: relaciones laborales; supervisión de enfermería; salud pública; organizaciones internacionales

\section{FLEXIBILIZAÇÃO E DESREGULAMENTAÇÃO LABORAL DOS TRABALHADORES DA ÁREA DE ENFERMAGEM NO BRASIL: O CASO PROFAE}

Este estudo analisou o processo de flexibilização das relações de trabalho na implementação do Projeto de Profissionalização dos Trabalhadores da Área de Enfermagem (PROFAE), no Brasil. Trata-se de estudo qualitativo, tendo como marco teórico-metodológico o materialismo histórico e dialético. Foram realizadas entrevistas dirigidas, com questões abertas e submetidas ao procedimento de análise do discurso. Os resultados evidenciam o processo de flexibilização e de desregulamentação das relações de trabalho na área de saúde do Brasil, caracterizado pelos seguintes elementos: pagamento por produção, divisão fragmentada do trabalho, critérios de remuneração salarial variável, profissionais qualificados e polivalentes, sensação de liberdade profissional, reduzida governabilidade e poder decisório, múltiplos vínculos, programação de atividades substituindo modelos de planejamento e maciça operacionalização sistemática das ações.

DESCRITORES: relações trabalhistas; supervisão de enfermagem; saúde pública; organismos internacionais

${ }^{1}$ PhD in Nursing, Faculty, Brasilia University, Brazil, e-mail: solbaraldi@unb.br; ${ }^{2}$ PhD in Nursing. Faculty, University of Sao Paulo School of Nursing, Brazil, e mail: marcrcar@cce.usp.br 


\section{INTRODUCTION}

Nowadays, it is relevant to understand the mechanisms that give rise to flexible and precarious work. The present stage of capitalism considers the deregulation of markets, including the work market, as an essential strategy for overcoming capitalism's structural crisis ${ }^{(1-3)}$. Hence, the need to create public policies that consider such questions has gained great relevance.

Brazilian labor legislation has been facing changes, sometimes subtle, other times explicit, which facilitate the heterogeneity of the contract relations between employer and employee, and minimize or eliminate labor rights ${ }^{(4)}$. These changes take place in a socioeconomic context that is characterized by high rates of unemployment, in Brazil ${ }^{(5)}$ and around the world. From this unemployment scene, along with the scarce access to different resources, various forms of exclusion arise.

Flexible labor is characterized by several service delivery contracts with a maximum duration of two years, according to article 445 of CLT (Consolidation of Brazilian Labor Laws) $^{(4)}$. This process constitutes one of the greatest challenges for workers in general, and particularly for those in the health area, since what is presented as the positive capacity of adaptation to different realities (flexibility), actually hides what European authors call labor "casualisation / precarisation" ${ }^{\prime 2}$. Concerning the flexible relationship of labor, the existence of two different models can be identified for the same process ${ }^{(6)}$ :

- European: internal flexibility and institutionalized management. This internal flexibility makes it possible to face the market unpredictability, "based on the systematic construction of qualified and versatile professionals, capable of taking initiative and making decisions", and aimed at "protecting and improving the professionals' living conditions while allowing competitiveness and labor". Nevertheless, it requires the reduction in work hours, wage levels and the division of work in varied ways, in which guarantees of social protection are not fundamentally suppressed;

- American: external deregulation and flexibility, characterized by the "multiplication of the weakened forms of labor (reduction of fixed labor costs, refusal of labor's social achievements, generalization of temporary contracts, softening labor and social protection legislation, and implementation of performance-based wages...)". Although this model is linked to the idea of economic development and large-scale job generation in the United States, some authors state that economic growth and employment generation in the United States are not justified by the flexibilization of the job market, as they are generated by the flow of international capital towards this economy, which is capable of stimulating it ${ }^{(7)}$.

Brazil seems to incorporate the American model over the European one, according to several changes in the CLT, such as:

- new part-time labor modality, characterized by the reduction of the workweek, with a proportional wage reduction and the institution of the "hour bank ", which presents an increase in the compensation for hours worked overtime. According to the production needs, the employer may demand that employees work overtime. However, there are losses from the remuneration perspective, as these hours will become regular hours instead of overtime, with a similar value in the flexible working system. That is, one hour of work, during regular work hours, can be exchanged for another hour without work in the regular work period;

- labor contract for an established period and other provisions (Law 9601/98);

- free negotiation between parties and the prohibition of wage indexation;

- sharing of profits and results (Law 10.101/00), as an incentive to increase productivity.

Along with the set of changes in Brazilian political-legal rules, concerning the employeremployee relationship in private companies, in the executive branch of the public sector, the limitation of expenses with civil servants is observed in $50 \%$ of the current federal net revenue for the Union; 60\% of the current net revenue for states and the federal district; and $60 \%$ of the current net revenue for municipalities. The latter motivated combined contracts (CLT and flexible/outsourcing, etc.) in the public sector, in order to complement the staff needed in view of the established budget, which, in general, does not meet the expectations of functional contracting.

Thus, the neoliberal scenario directly affects the political-legal forms of labor relationships, both in public and private services, little by little instituting a flexible work market. This option results in the acceptance of labor laws as "privileges" and, thus, legitimizes the exclusion of entire economies in the globalized market ${ }^{(7)}$. 
Health professionals are slowly affected by the deregulation of the work market. In the late 80's and early 90's, the deregulation of labor relations in the health area becomes part of the Single Health System $^{(7)}$ agenda, by outsourcing health services, generally through cooperatives. Nowadays, at the beginning of the $21^{\text {st }}$ century, the deregulation process of the work market has reached the Brazilian Constitution and the Consolidation of Labor Laws.

This way, even though the health area is not yet facing a massive unemployment scene when compared to other economy areas, it is observed that flexibilization processes are being evidenced. This indicates losses from the perspective of remuneration and working hours, in which multiple jobs are a historical characteristic. In addition, labor fragmentation has been stimulated, among other factors, leading to the gradual disqualification of population care. Therefore, it is legitimate that workers' social rights be preserved in all positions - CLT, statutory, cooperative, autonomous and outsourced - among the several types of relationships developed.

Based on this information, this study aims to analyze the flexibilization process of labor relationships in the implementation of the PROFAE Professionalization Project of Nursing Workers in Brazil.

\section{METHODOLOGY}

The framework used in this study was historical-dialectal materialism, since it considers the possibilities and, thus, permits examining the object in its social context, acknowledging that the existence of contradictions, complexities and paradoxes is inherent to the analysis categories ${ }^{(8)}$. This conception favored the qualitative analysis of the Nursing work process and its elements related to the flexibilization process of labor relationships brought about by governmental strategies for putting in practice the neoliberal policy and its political micro-dynamics. The work process in the health area was elected as the analytical category, described as follows.

The work process and flexibility as a constituent element

Labor constitutes the main mediation instrument in the Man-Nature relationship. The work process, which takes place and institutes the subjective level, aims to achieve "(...) relationships with the working objects and instruments and, when the process is complete, at the same time, there should be results, such as: products, enlarged re-production of the natural forces dominated, reproduction of the social relations regarding the objects and instrument and, inside and through it all, the re-production of the workers"(9).

The labor deregulation and flexibilization process did not happen at random in a historical, social and economic context of the capitalist society, and its socio-historical apprehension occurs in the interaction between the needs of the individual (subject) and society as a whole. Thus, this study will use the intrinsic aspects of the nursing work process in public administration, aiming to permit an understanding of the possible connections in the theoretical and practical levels of the organized PROFAE work process.

PROFAE was selected as the scenario for this study because it is a national project, its object of intervention aims at nursing, and, mainly, because it relies on international funding for its implementation. Therefore, it is subject to the mediation of international organizations for the construction of its management model.

The organizational architecture of PROFAE includes two structures: Component I (Professionalization and Education) and Component II (School Modernization, Competency Certification, Signs of the Health Work Market and Pedagogical Training). Component I mainly aimed at providing education and professional qualification to students with basic education deficits, who have been identified as Nursing workers in public or private health services. In another range of the same object, Component II aimed to strengthen SUS technical schools; create and implement a Certification System for Competencies, for graduated students; an Information System about the Health Work Market; and the supply of Pedagogical Training for PROFAE teachers ${ }^{(10)}$.

The execution of Component I actions, was evaluated by an organizational structure named Regional Agency (AR), as well as in other internationally accredited governmental projects, often indicated by instances monitoring the project.

As an organization of private or public rights, contracted by the Health Department after a bidding process, i.e. not directly connected to the project instances and recognized as "partners", the AR had 
the social role of follow-up and monitoring, which was put in practice by the supervision of the training groups. These aspects justify the election of the AR as a concrete reality for doing research.

The specific object for analysis was the supervision process, performed in the professional training groups, under the responsibility of Component I, since the supervision, as one nursing work instrument, is present in different working processes in nursing (care, management and education) ${ }^{(11)}$.

The theoretical supervision proposal of PROFAE's courses suggested monitoring and evaluating the pedagogical process of the groups available at schools, moving away from the concept of supervision as an exclusive practice for control, in order to guarantee the quality of the professionalization process for the people participating in the subprojects: Professional training of Nursing Assistants, Complementary Professional Training and Complementary Basic Education. It was expected that "besides detecting the problems/difficulties and seeking solutions in the management and educational fields, it is the responsibility of the Supervisor to act as an agent of a dialogical process, articulating the professional education of nursing assistants/ technicians with PROFAE principles"(10).

Scenario, study subjects and data collection procedures

Public and private Regional Agencies in the South and Southeast were visited, and nurses who acted as coordinators and supervisors were interviewed. Documents that supported the supervision process (reports, instruments, manuals, etc.) in these instances and in PROFAE management were also analyzed.

Two different instruments were used for the interviews. The form Characterization of the Subjects' Social Inclusion consisted of closed questions, which were common to everyone, as it constitutes one of the main variables for the socioeconomic identification of the subjects. Different from this form, the interview script considered the differentiated roles between coordinator and supervisor, as follows:

- Coordinators and Supervisors: 1. Identification; 2. Education; 3. Occupation.

- Coordinators: 1-Describe, as detailed as you can, how you plan the nurses' supervision in the professional training groups.
- Supervisors: 1- Describe, as detailed as you can, one of your supervision work days. 2- What do think and feel about this job?

The Free and Informed Consent form was signed after the explanation of the purposes and the procedures that would be followed during the interview, fully complying with the requisites of the Research Ethics Committee at the University of São Paulo School of Nursing (Process No. 253/2002/CEPEEUSP).

\section{DATA ANALYSIS}

The study data were obtained in the directed interviews through open-ended questions that were recorded, fully transcribed and then submitted to discourse analysis(12). The discourse analysis procedure comprehended the following stages: a) reading the discourses repeatedly; b) identifying the subtopics addressed in the statements; c) writing the subtopics as thematic sentences; d) grouping the thematic sentences by congruencies and similarities for the identification of empirical categories.

The technique used for decoding the interviews was used to design a corpus consisting of 19 interviews (seven with coordinators and 12 with supervisors), which presents a repeated theme in the statements, with few peculiarities. The dialog established among the corpuses (sets of thematic sentences), the work process as an analytical category, from the perspective of the dialectic categories $^{(13)}$ "need and casualness", "possibility and reality" and "essence and phenomenon", allowed for the validation the empirical category elements of the flexible work process.

\section{RESULTS AND DISCUSSION}

Thirty-nine nurses, nine coordinators and thirty supervisors from seven ARs were interviewed. Most of them were postgraduates: two Ph.D.'s, 14 Master's degrees and 18 specialists. In terms of remuneration, Ph.D.'s earned the best wages when compared to the other professionals interviewed. As for Master's, specialists and graduates, the differences among these figures were $34 \%, 63 \%$ and $84 \%$, respectively. Regarding the average workweek, Ph.D.'s dedicate more time and work $4 \%$ more than 
Master's, 36\% more than specialists and three times more than graduates.

The study indicated that most of the professionals had multiple jobs - in general, a combination of formal and informal jobs, in order to assure some labor benefits. Concerning the contract closed by the ARs, the absolute majority (37) did not have a formal labor relation, that is, both institutions - despite the differentiated legal nature - work in similar ways in the recruitment of their employees. The Project was seen as an interesting alternative for increasing their income.

It is sometimes hard (...). We work and, afterwards, we perform the supervision at some time.

Most of the newly graduated nurses or from 22 to 30 years old had only one labor relation, which indicated that they were part of a flexible work regimen and did not benefit from social protection. This suggests that the professional deregulation already reaches the younger professionals, who start their career in a legally flexible labor relation.

This situation is very different for nurses who are around 30 years old and older, who reported that they benefit from a certain degree of social protection, including pension, once they are sub judice of previous labor laws, or even due to their history of stable and "more permanent" labor relations.

In this kind of service delivery to PROFAE, the discourse showed work was performed in the models of payment by production, i.e. by the number of groups supervised, later consolidated in a report that authorized the remuneration of these supervisors/ coordinators. According to PROFAE rules and guidelines ${ }^{(10)}$, the supervision aims both to qualify the professionalization process offered by the schools and to validate the payment of the establishments contracted through invoices, according to the different hierarchical levels of execution and report, as the payment of a procedure implies other payments, and so on. For the researchers, this element outlines the implicit and explicit mechanisms in the flexible labor process which, despite being a particular situation, explicit the exchange of values of the capitalist society, instituting the "bargaining currency " for the class that makes a living from work.

According to the bidding specifications ${ }^{(14)}$ used in the process for hiring the AR's, the degree criterion (graduate degree) was not an essential requirement. Nevertheless, as it was one of the eligibility criteria of the ARs with differentiated scoring (score 1, 2 and 3),
PROFAE actually selected professionals who held degrees (Master's and Ph.D.'s) as a differential among the organizations that competed for the tenders. This search for professionals who are qualified, "multifunctional" and "versatile" is one of the characteristics of the current process of capital (re)production ${ }^{(1-2)}$, exemplifying the dialectical relation between the phenomenon (qualified labor, multiple jobs in order to increase a decreasing individual income, etc.) and the essence (producing more, better, in a shorter period of time and the appropriation of more value).

Regarding the execution of the supervision work, the statements were generally limited to the casual level of the facts, emphasizing the operational aspect, cleared from pedagogical content, at least in its instrumental materialization form: reports, visits, schedules, demands, invoices etc. Concerning the time dedicated to labor, supervisors mentioned three or four days of work, either because they monitor groups far from home or because they took on a large number of groups.

In the distribution of the quantity of groups, the coordination reasons that: the ones who are closer to home take more groups, to facilitate who is out.

Considering the reality of multiple jobs, it was recognized that this kind of job facilitated (possibility) the subject's life, as it allowed for planning in a more autonomous way, even though associated to the regret about the impossibility (reality) of better dedication, especially in the construction of relations with the students, as this is one of these professionals'.

The supervisor uses an average of two/three days to visit 17 groups (three in the morning, six in the afternoon and eight in the evening) and, whenever she has the opportunity, she discusses a subject with the students in approximately twothree groups a month, also "to get a little closer to them".

In relation to the meaning provided by the PROFAE work process, there was the expectation that the supervisor were a "super supervisor", as may be perceived by reading the PROFAE supervision guide. In general, the act of making decisions was partially within its reach. The work enabled the dialogue or the acknowledgement of the relation among the actors involved, but faced their performance limits (reality), since a dense pedagogical and political component, which they did not master, was demanded from them, added to the fact that the decisions are associated to a complex network of actors and have a delimited execution time. 
The following situations were presented as examples, demanding specific formulation and resolutions from the several actors (local, regional or national scale): delay or lack of the scholarship payment; delay in the delivery of the students' books; outdated Information Management System; the employer's non authorization for the students to leave; the guarantee that the student will take the whole course and graduate as a Nursing technician. A supervisor with characteristics of a "transformer" of the reality ${ }^{(10)}$ was expected, but he was more involved in support for making decisions (essence) than in really deciding and "transforming" (phenomenon). The expectation (possibility) of the coordinators, as for the profile of the supervisors, is that they have enough experience to make decisions and respond to the demands, preventing that more problems are taken to the coordination. They negatively evaluate (reality) the fact that even the "good nurses", who are committed to their job, ignore some basic teaching instruments, demanding the coordinators' time for simplified training processes. The coordination seemed to exempt itself from one of its basic functions: the continuous development of the professionals. In this context, as revelation of the work process' essence, the demonstration of the real phenomenon, from the discourse, makes this study question the quality of the flexible workers' performance, who seem to comply with an apparent creation of the product (report) contracted, evidencing a serious contradiction with the phenomenon represented in the professional qualification policy, involving interfaces between the world of education and labor, and corroborating the examined literature ${ }^{(15)}$.

Good nurses and field professionals, committed to the care process, to health, to the education of human resources, do not know what a pedagogical project is, what a schedule is, a class plan, evaluation strategies, and then you spend a lot of time training them.

One situation, although specific, is worth mentioning: it was the statement of a coordinator about the fact that, considering the AR contract renewal and the Project expense restraint, a bimonthly visit should be agreed upon, instead of a monthly one, which would reduce the supervisors' remuneration. Contemporaneous workers face the challenge to understand that the reality implicit in the flexible regimen necessarily brings them the possibility of a little stable job.
The coordinator informs that an agreement was made between PROFAE and the $A R$, due to the expense restraint, in which the report will be presented bimonthly instead of monthly, displeasing the supervisors who "earn for each visit performed".

\section{CONCLUSIONS}

The results of the research suggest that the deregulation process of labor relations reaches the health professionals, through the recruitment for governmental projects and/or programs with international funding. Flexible labor relations can be characterized by the following elements:

- The political-administrative conception implemented in this period created conditions for the implementation and/or maintenance of these labor relations inside the State - in particular, the lack of public contests may have justified, in most of the cases, the flexible recruitment of professionals;

- The professionals with graduate degrees (Master's and Ph.D.) did not escape from the multiple jobs to complement their income in a flexible labor regimen; - The deregulation process of labor relations has favored the introduction of young professionals in line with the dynamics of flexible/informal labor, which is generally the only relation this worker is supported by. On the other hand, professionals who started their job under the CLT regimen before the deregulation process have a complementary basis for their budget, in the flexible job, as the formal single relation does not completely respond to their needs;

- The supervision process performed by the supervisors/ARs was found fragmented and mostly related to control, both in the repetitive description of the activities related to the checking of the "units" (schools, students, professors, instruments and reports, etc.), and in the overrating of the report and low level of articulations with political actors, necessary for a supervision process that would guarantee the execution of its purposes and aims;

- The public competition process, with differentiated score for the matter of degree, favored the search (and continuation) of professionals with Master's and Ph.D. degrees in the composition of their teams. However, these professionals' decision-making power was reduced and their governability compromised, as the complexity of the problems came from their own project rules (scholarship, variable criteria in the inclusion of the students into the courses, 
'precarious' control of the number of students in the information system, school dynamics, teaching regulation, etc.) and from the scenario of actors inherent in the implementation of public policies, generally not harmonious, bringing up tensions originating in the interests of the actors involved (federal, municipal and state levels; international organizations; state departments; class associations; schools and the ARs).
For the sake of reflection, it is relevant to discuss the deconstruction of social rights, historically achieved by workers, aiming at the (re)construction of public policies that favor the humanization of labor relations. The latter becomes relevant because the role of the State has been evidenced as active and inducing the creation of flexible forms of labor in the health area in Brazil, in other words, in the materialization of the neoliberal political ideology and strategies.

\section{REFERENCES}

1. Antunes R. Os sentidos do trabalho. São Paulo (SP): Boitempo Editorial; 2003.

2. Mészáros I. Desemprego precarização: um grande desafio para a esquerda. Resistir. Info [periódico na Internet]. 2003 Junho [acesso em 2006 Set 30];1(2):[aproximadamente 30 p.]. Disponível em: http://resistir.info/crise/ desemprego_precarizacao.html

3. Beck U. The brave new world of work. Cambridge: Polity Press; 1999.

4. Brasil. Consolidação das Leis do Trabalho. 10.ed. - São Paulo: Rideel; 2004. (coleção de leis Rideel).

5. Ponchman M. O emprego na globalização: a nova divisão internacional do trabalho e os caminhos que o Brasil escolheu. São Paulo (SP): Boitempo; 2002.

6. Coriat B. Novas tendências do mercado de trabalho. Rev Serv Público 1998; 49(3):5-29.

7. Almeida AS. Desemprego e precarização das condições de trabalho nos países avançados. [dissertação] Campinas (SP): Universidade de Campinas; 2003.

8. Demo P. Metodologia do conhecimento científico. São Paulo (SP): Atlas; 2000.

9. Gonçalves RBM. Práticas de saúde: processo de trabalho e necessidades. São Paulo (SP): Departamento de Medicina Preventiva da Faculdade de Medicina da USP; 1992. 94 p. mimeografado.

10. Ministério da Saúde (BR). Projeto de Profissionalização dos Trabalhadores da Área de Enfermagem. Documento de orientação: supervisão do Profae. Brasília (DF): Ministério da Saúde; 2001. (Série A. Normas e Manuais Técnicos, 121). 11. Silva EM. Supervisão em enfermagem: análise crítica das publicações no Brasil dos anos 30 à década de 80 . [dissertação] Ribeirão Preto (SP): Escola de Enfermagem da USP; 1991.

12. Car MR, Bertolozzi, MR. O procedimento da análise de discurso. In: A Classificação Internacional das Práticas de Enfermagem em Saúde Coletiva-CIPESC. Brasília (DF): ABEn; 1999. p. 348-55. (Série Didática: Enfermagem no SUS).

13. Cheptulin A. A dialética materialista: categorias e leis da dialética. São Paulo: Alfa-Omega; 1976.
14. Ministério da Saúde (BR). Secretaria de Investimentos em Saúde. Edital: Projeto de Profissionalização dos Trabalhadores da Área de Enfermagem. Regiões Sul e Sudeste. Brasília (DF): Ministério da Saúde; 2000.

15. Benach J, Amable M, Muntaner C, Benavides FG. The consequences of flexible work for health: are we looking at the right place? J Epidemiol Community Health 2002; $56(6): 405-6$ 